\title{
Inclusive Special School Teachers' Self-Assessment of their Diagnostic and Therapeutic Knowledge and Skills
}

\begin{abstract}
Anna Borzęcka, Inclusive Special School Teachers' Self-Assessment of their Diagnostic and Therapeutic Knowledge and Skills. Interdisciplinary Contexts of Special Pedagogy, no. 27, Poznań 2019. Pp. 181-195. Adam Mickiewicz University Press. ISSN 2300-391X. e-ISSN 2658-283X. DOI: https://doi.org/10.14746/ikps.2019.27.09

Diagnostic and therapeutic competences are necessary for the effectiveness of didactic and educational interventions undertaken by a professional specialist school teacher. In order for the teacher to be able to cope with the tasks assigned by special pedagogy, he must have theoretical and practical preparation in the field of diagnosis and therapy. The future of a special school pupil will depend on his knowledge and skills. The article presents research on declarative sources of teaching knowledge and skills in the field of diagnosis and therapy as well as their selfassessment, taking into account nominal variables (age and job seniority).
\end{abstract}

KEY WORDS: diagnostic competences, therapeutic competences, knowledge selfassessment, self-assessment of skills

\section{Introduction}

A special school teacher implements activities determined through special education, for which "the subject are the care, therapy, education and upbringing of persons with divergences from the norm, in most cases less able or disabled individuals, irrespec- 
tive of the type, level and complexity of symptoms as well as the causes and effects of the anomalies, disturbances, difficulties or limitations that emerge" ${ }^{\prime 1}$. The professional role of a special school teacher is to organise didactic and educational as well as rehabilitation activity that is aimed at the comprehensive development of a disabled person in line with their individual psychological and physical capacities, the transfer of knowledge, the establishment of faith in their own capacity to act and self-esteem, the instilment of the passion for work ${ }^{2}$. The effects of education and of the upbringing of pupils with special education needs largely depend on the competences of the teacher.

The concept of competences is used in at least two meanings: "first of all, competences are identified with qualifications, and second of all the concept of competences describes a set of rights or privileges"3. According to W. Strykowski, competences are "knowledge, skills and convictions needed for efficient didactic, educational and care work at a school"4. R. Pachociński believes that a teacher in a contemporary school stops being the main source of information about the world for pupils, and rather becomes a diagnostician, a specialist in the area of learning aids, a consultant ${ }^{5}$.

Many competences in subject literature include diagnostic and therapeutic competences that are necessary for the effectiveness of didactic and educational activity ${ }^{6}$.

${ }^{1}$ W. Dykcik, Wprowadzenie w przedmiot pedagogiki specjalnej jako nauki, [in:] Pedagogika specjalna, ed. W. Dykcik, Wydawnictwo Naukowe UAM, Poznań 2005, p. 13.

2 A. Korzon, Motywy wyboru zawodu pedagoga specjalnego, [in:] Kompetencje pedagoga w kontekście teorii i praktyki edukacji specjalnej, ed. P. Majewicz and A. Mikrut, Oficyna Wydawnicza „Impuls”, Gliwice - Kraków 2008, p. 34.

${ }^{3}$ W. Strykowski, Nauczyciel i jego kompetencje, [in:] Kompetencje nauczyciela szkoty wspótczesnej, ed. W. Strykowski, J. Strykowska, J. Pielachowski, Wydawnictwo „eMPi2”, Poznań 2007, p. 69.

4 Ibidem, p. 80.

5 See A. Gajdzica, Kompetencje nauczyciela we współczesnej szkole, [in:] Uczeń niepetnosprawny $i$ jego nauczyciel w przestrzeni szkoły, ed. Z Gajdzica, J. Rottermund, A. Klinik, Oficyna Wydawnicza „Impuls”, Kraków 2008, p. 18.

${ }^{6}$ D. Wosik-Kawala, T. Zubrzycka-Maciąg, Kompetencje diagnostyczne i terapeutyczne nauczyciela, Oficyna Wydawnicza „Impuls”, Kraków 2018, p. 7. 
Diagnostic competences, related to getting to know the pupils and their environment, "provide the ability of determining of an individual's specific needs and capacities, serving mainly the determination of disability and of very general indications of rehabilitation 7 . The diagnostic competence of a teacher is a condition of optimum and efficient discovery of capacities, skills, difficulties and needs of those under their care and of pupils, both in the individual as well as in the group perspective, taking into account their weak and strong suits, their health, perception and cognitive abilities, as well as the conditions of the environment they are growing up in ${ }^{8}$.

Therapeutic competences encompass skilful observation, listening and speaking as well as reactions of the teacher in order to get to know a pupil - their expectations and problems, with particular focus on countering difficulties in adaptation (to the school environment) and in development ${ }^{9}$.

The future of a special school pupil, his psychological and physical development, his successes, his individuality, joy or personal happiness will depend on the teacher's knowledge and skills.

\section{Methodological assumptions and study results}

The study was conducted in the Silesian Voivodeship in six special schools selected at random. It encompassed 118 teachers working with children with special education needs, where the largest part $(31.4 \%)$ are persons aged $30-39$ and $40-49$ years. $22.0 \%$ of those

7 Zob. A. Borzęcka, Kompetencje nauczyciela - pedagogaspecjalnego w pracy z uczniem ze specjalnymi potrzebami edukacyjnymi, [in:] Nauczyciel-Dziecko. Spotkania w przestrzeni edukacyjnej, ed., A. Borzęcka, A. Twaróg-Kanus, Wydawnictwo LIBRON - Filip Lohner, Kraków 2018, p. 90.

${ }^{8}$ See M. Klimek, Kompetencje diagnostyczne nauczyciela w kontekście pomocy psychologiczno-pedagogicznej w szkole, Lubelski Rocznik Pedagogiczny, vol. XXXV, issue 1 - 2016, p. 168.

9 T. Pilch, ed., Encyklopedia pedagogiczna XXI wieku, vol. IV, Wydawnictwo "Żak”, Warszawa 2004, p. 944. 
surveyed are fifty years old or more. The remaining respondents $(15.3 \%)$ are persons aged $20-29$ years. The respondents participating in the study are teachers with a varied volume of work experience, whereby the largest group (37.3\%) has over 20 years of experience. $34.7 \%$ of those surveyed have between eleven and 20 years of work experience. The smallest group are teachers who have been working ten years or less $(28.0 \%)$. $98.3 \%$ special school teachers have additional qualifications, with only $1.7 \%$ not holding professional qualifications.

The objective of the study was an analysis of sources of knowledge and skills concerning diagnosis and therapy as declared by the analysed special school teachers and their self-assessment as well as an analysis of the relationship between the declared assessment with their age and work experience.

The following research problems were described:

1. What are the sources of diagnostic and therapeutic knowledge and skills of the analysed special school teachers?

2. How do the analysed special school teachers assess their diagnostic and therapeutic knowledge and skills?

3. Does the age of the analysed special school teachers condition their self-assessment of diagnostic and therapeutic knowledge and skills, and to what extent?

4. Does the work experience of the analysed special school teachers condition their self-assessment of diagnostic and therapeutic knowledge and skills, and to what extent?

The study uses a special school teacher survey questionnaire. All data is entirely anonymous and was used exclusively for scientific purposes.

The analysis was divided into two parts. The chi-square and Fisher tests were applied to nominal variables that enable an analysis of whether the independent variables named above (age and work experience) and self-assessment of diagnostic and therapeutic knowledge and skills exhibit a statistically significant correlation. 
On the basis of the previously assumed scale from one to five, variables were analysed concerning the self-assessment of knowledge and skills. Non-parametric U Mann-Whitney as well as Kruskal-Wallis tests were used. For all analysis, a significance level of $p=0.05$ was assumed.

The presented study are a fragment of a broader research project concerning the diagnostic and therapeutic competences of public, integration and special school teachers.

For the purposes of this study, the subdivision of knowledge and skills is the subdivision presented by Z. Gajdzica ${ }^{10}$.

On the basis of the collected data (Diagram 1 and 2) concerning the sources of knowledge and skills in terms of diagnosis and therapy

Diagram 1. Sources of knowledge as declared by special school teachers

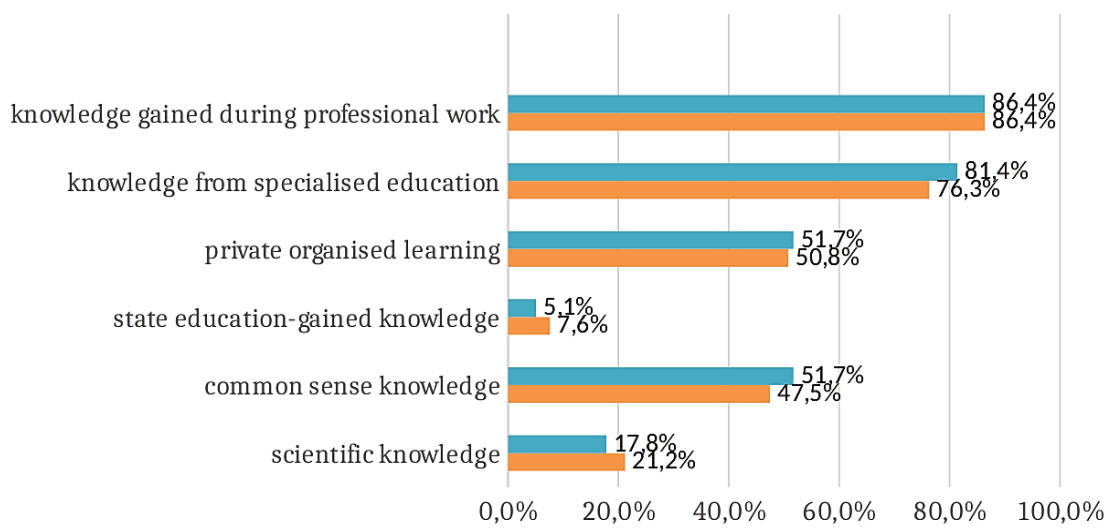

$\square$ knowledge in terms of diagnosis $\square$ knowledge in terms of therapy

Source: own work.

${ }^{10}$ Z. Gajdzica, Źródła wiedzy polskich i czeskich nauczycieli, "Studia Edukacyjne” 2013, no. 24, pp. 103-114; Z Gajdzica, Założenia znam z ... - czyli o kreowaniu opinii nauczycieli na temat przemian ksztatcenia specjalnego, „Teraźniejszość - Człowiek Edukacja" 2011, no. 4(56). 
as declared by the analysed special school teachers, one may conclude that the sources of knowledge most commonly indicated in terms of diagnosis include knowledge gained during professional employment $(86.4 \%)$, knowledge from their own specialist education $(76.3 \%)$ and knowledge gained through additional private courses $(50.8 \%)$. Common and scientific knowledge is indicated by $47.5 \%$ and $21.2 \%$ of those surveyed, respectively. The remaining participants in the study $(7.6 \%)$ utilise knowledge gained through their state education. The most commonly indicated sources of knowledge in terms of therapy are knowledge gained during work $(86.4 \%)$ and knowledge from own specialist education (81.4\%). Knowledge gained during private courses and common sense knowledge is indicated by $51.7 \%$ of those studied. The remaining respondents to the survey utilise scientific knowledge $(17.8 \%)$ and knowledge gained from state education (5.1\%).

Diagram 2. Sources of skills as indicated by the analysed special school teachers

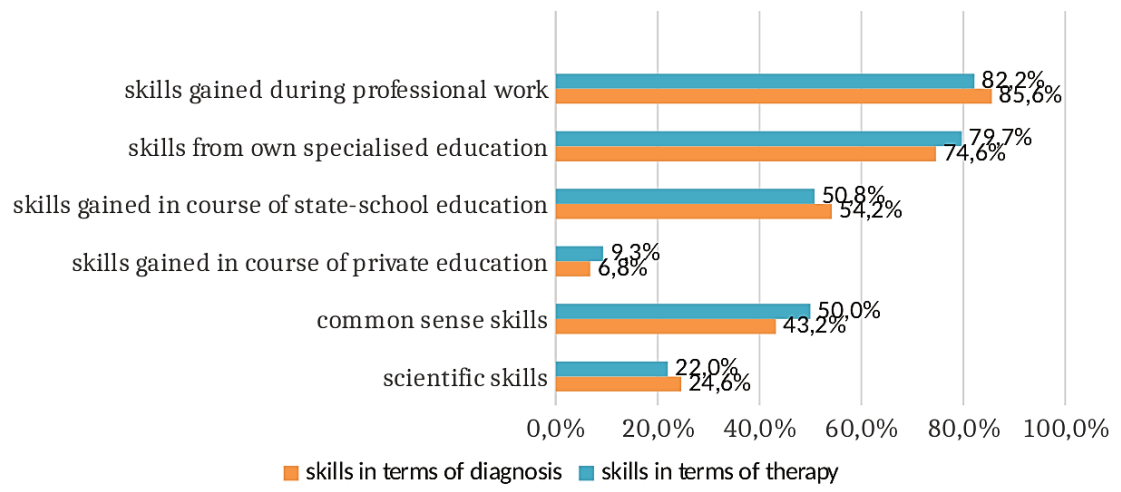

Source: own work.

In terms of diagnostic skills, the skills most commonly indicated are those gained in course of professional work $(85.6 \%)$, skills from own specialist education (74.6\%) and skills gained during of additional private courses (54.2\%). $43.2 \%$ and $24.6 \%$ of respondents, re- 
spectively, indicate using common sense and scientific knowledge. The remaining surveyed teachers $(6.8 \%)$ utilise knowledge gained in course of their state education. The most commonly used sources of skills in terms of therapy are skills gained during professional work $(82.2 \%)$, skills from own specialist education $(79.7 \%)$ and skills gained through private courses (50.8\%). 50.0\% and $22.0 \%$ of those surveyed indicate having common sense and scientific knowledge, respectively. $9.3 \%$ of those surveyed in turn use knowledge gained in course of state education.

A further issue (Diagrams 3 and 4) concerned the assessment of their knowledge and skills in terms of diagnosis and therapy by the analysed special school teachers.

Diagram 3. Self-assessment of knowledge by special school teachers $60,0 \%$

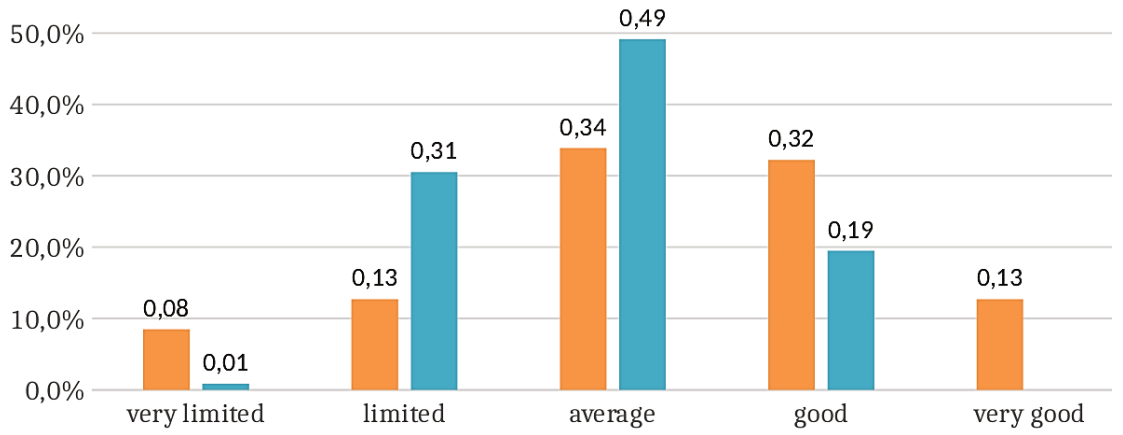

$\square$ knowledge in terms of diagnosis $\square$ knowledge in terms of therapy

Source: own work.

Knowledge in terms of diagnosis was assessed by the studied teachers to be average $(33.9 \%)$ or good $(32.2 \%)$. $12.7 \%$ each of the respondents in this group believe that their knowledge is either very good or limited. $8.5 \%$ of those surveyed indicated that their knowledge in this regard is very limited. In terms of knowledge on therapy, $49.2 \%$ of those surveyed indicate it as being average, and 
$30.5 \%$ of those indicated that it was limited. $19.5 \%$ of the survey participants believe that their knowledge is good. $0.8 \%$ persons in this group hold their level of knowledge in this regard to be very limited.

Diagram 4. Self-assessment of skills of special school teachers

$60,0 \%$

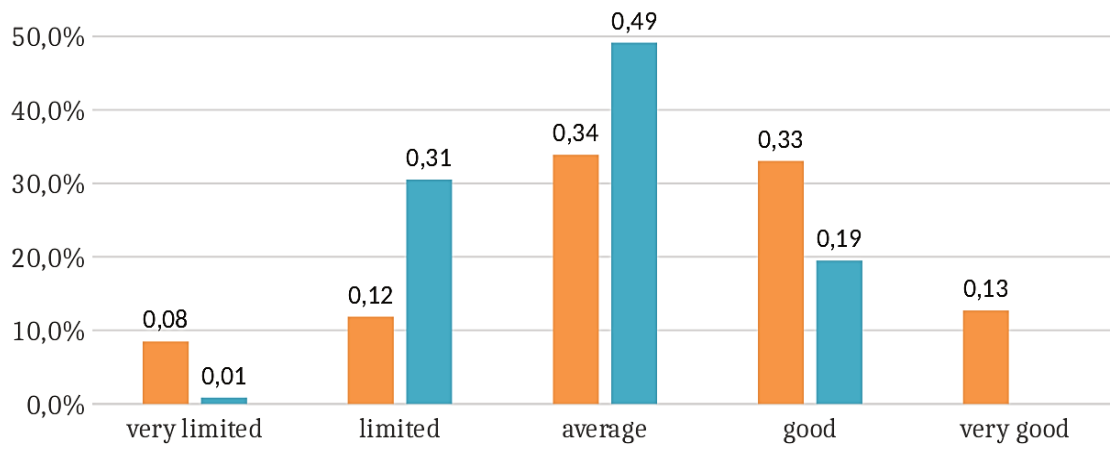

n skills in terms of diagnosis $\square$ skills in terms of therapy

In the opinion of $33.9 \%$ of respondents, their diagnosing skills are average. Good and very good diagnosing skills were indicated by $33.1 \%$ and $12.7 \%$ of respondents of the study, respectively. $11.9 \%$ persons from this group evaluate these skills as limited, and $8.5 \%$ as very limited. In terms of therapy skills, $49.2 \%$ of those surveyed believe they are average, and $19.5 \%$ indicate that they are good. $30.5 \%$ of those surveyed believe their therapy skills to be limited. According to $0.8 \%$ of respondents, they are very limited.

A data analysis was conducted (table 1) in order to determine the relation between the age of the analysed teachers and the knowledge and skills they had in terms of diagnosis and therapy.

Statistically significant differences in terms of knowledge in terms of diagnosis are found between teachers aged 20-39 years and teachers aged 40 years and over $(U=977.00, p<0.05)$. Among the 
analysed teachers from the first group, the results remained within the range from Min. $=1$ to Max. = 5. The median score in this group was $M e=3$, meaning that at least half of the analysed persons achieved a result not exceeding this level. Among those analysed from the second group, the results were higher - they were limited by the values of Min. = 2 and Max. = 5; for a quarter of the analysed teachers, they did not exceed $Q 25=3$, and for half they did not exceed $M e=3$; for three quarters they did not exceed $Q 75=4$. This indicates that teachers aged 40 years and over evaluated their knowledge in terms of diagnosis higher.

Table no. 1. Age of the studied teachers and the knowledge and skills held in terms of diagnosis and therapy

\begin{tabular}{|c|c|c|c|c|c|c|c|c|c|c|}
\hline $\begin{array}{c}\text { Self-assessment of } \\
\text { knowledge and skills }\end{array}$ & Age & $M$ & $S D$ & Min. & $Q 25$ & $\mathrm{Me}$ & $Q 75$ & Max. & $U$ & $p$ \\
\hline \multirow{2}{*}{$\begin{array}{l}\text { Knowledge in terms } \\
\text { of diagnosis }\end{array}$} & 20-39 years & 2.8 & 1.1 & 1.0 & 2.0 & 3.0 & 4.0 & 5.0 & \multirow{2}{*}{977.00} & \multirow{2}{*}{0.000} \\
\hline & 40 years and over & 3.7 & 0.9 & 2.0 & 3.0 & 4.0 & 4.0 & 5.0 & & \\
\hline \multirow{2}{*}{$\begin{array}{l}\text { Knowledge in terms } \\
\text { of therapy }\end{array}$} & $20-39$ years & 3.5 & 0.6 & 2.0 & 3.0 & 3.0 & 4.0 & 5.0 & \multirow{2}{*}{904.50} & \multirow{2}{*}{0.000} \\
\hline & 40 years and over & 4.2 & 0.7 & 3.0 & 4.0 & 4.0 & 5.0 & 5.0 & & \\
\hline \multirow{2}{*}{$\begin{array}{l}\text { Skills in terms of exe- } \\
\text { cution of diagnosis }\end{array}$} & 20-39 years & 2.8 & 1.1 & 1.0 & 2.0 & 3.0 & 4.0 & 5.0 & \multirow{2}{*}{973.00} & \multirow{2}{*}{0.000} \\
\hline & 40 years and over & 3.7 & 0.9 & 2.0 & 3.0 & 4.0 & 4.0 & 5.0 & & \\
\hline \multirow{2}{*}{$\begin{array}{l}\text { Skills in terms } \\
\text { of therapy }\end{array}$} & 20-39 years & 3.5 & 0.6 & 2.0 & 3.0 & 3.0 & 4.0 & 5.0 & \multirow{2}{*}{904.50} & \multirow{2}{*}{0.000} \\
\hline & 40 years and over & 4.2 & 0.7 & 3.0 & 4.0 & 4.0 & 5.0 & 5.0 & & \\
\hline
\end{tabular}

$M$ - mean; SD - standard deviation; Min - minimum value; Max. - maximum value; $Q 25$ bottom quartile; $M e$ - median; $Q 75$ - top quartile, $U$ - U Mann-Whitney test, $p$ - significance.

There are statistically significant differences concerning knowledge on therapy between teachers aged 20-39 years and teachers aged 40 years and over $(U=904.50, p<0.05)$. Among those analysed in the first group, the results remained in the range from Min. $=2$ to Max. $=5$. The median in this group was $M e=3$, meaning that at least half of the analysed teachers achieved a result not higher than this level. Among the teachers from the second group, the 
results were higher - they were limited by the values of Min. $=3$ and Max. = 5; for a quarter of the tested teachers they did not exceed the level of $Q 25=4$, for half they were not higher than $M e=4$, and for three quarters they were not higher than $Q 75=5$. This means that teachers aged 40 years and over assessed their knowledge in terms of therapy higher.

Statistically significant differences concerning skills in terms of execution of diagnosis were found between teachers aged 20-39 years and teachers aged 40 years and over $(U=973.00, p<0.05)$. Among those analysed in the first group, the scores were found in the range from Min. $=1$ to Max. $=5$. The mean in this group was $M e=3$, meaning that at least half of the studied teachers achieved a result not higher than this value. Among those analysed in the second group, the results were higher - they were limited by the values of Min. = 2 and Max. = 5; for a quarter of the analysed teachers, they did not exceed $Q 25=3$, for half they did not exceed $M e=4$, and for three quarters they did not exceed $Q 75=4$. One can conclude that persons aged 40 years and over assessed their skills in terms of diagnosis higher than younger teachers.

A statistically significant difference in terms of skills concerning therapy was found between teachers aged 20-39 years and teachers aged 40 years and over $(U=904.50, p<0.05)$. Among those analysed in the first group, the results remained within the range of Min. $=2$ to Max. $=5$. The median in this group was $M e=3$, meaning that at least half of the studied teachers achieved a result not higher than this level. Among those analysed in the second group, the results were higher - limited by values of Min. = 3 and Max. =5; in a quarter of the analysed teachers, they did not exceed the level of $Q 25=4$, in half they did not exceed $M e=4$, and in three quarters they did not exceed $Q 75=5$. The observation was made that teachers aged 40 years and over assessed their skills in terms of therapy higher than younger ones.

Due to the fact that $98.3 \%$ of the analysed special school teachers had additional qualifications, an independent variable that was tested was the work experience of special school teachers. 
The analysis (table 2) concerned the determination, whether the work experience of the analysed teachers is a condition of them having knowledge and skills in terms of diagnosis and therapy.

Table no. 2. Work experience and the knowledge and skills held in terms of diagnosis and therapy

\begin{tabular}{|c|c|c|c|c|c|c|c|c|c|c|c|}
\hline $\begin{array}{c}\text { Self-assessment of } \\
\text { knowledge and skills }\end{array}$ & $\begin{array}{c}\text { Work } \\
\text { experience }\end{array}$ & $M$ & $S D$ & Min & Q25 & Me & $Q 75$ & Max. & $x^{2}$ & $d f$ & $p$ \\
\hline \multirow{3}{*}{$\begin{array}{l}\text { Knowledge in terms } \\
\text { of diagnosis }\end{array}$} & less than 10 years & 2.45 & 1.18 & 1.0 & 1.0 & 2.0 & 3.0 & 5.0 & \multirow{3}{*}{24.482} & \multirow{3}{*}{2} & \multirow{3}{*}{0.000} \\
\hline & $11-20$ years & 3.39 & 0.92 & 1.0 & 3.0 & 3.0 & 4.0 & 5.0 & & & \\
\hline & over 20 years & 3.80 & 0.85 & 2.0 & 3.0 & 4.0 & 4.0 & 5.0 & & & \\
\hline \multirow{3}{*}{$\begin{array}{l}\text { Knowledge in terms } \\
\text { of therapy }\end{array}$} & less than 10 years & 3.21 & 0.48 & 2.0 & 3.0 & 3.0 & 3.0 & 4.0 & \multirow{3}{*}{43.025} & \multirow{3}{*}{2} & \multirow{3}{*}{0.000} \\
\hline & $11-20$ years & 3.98 & 0.65 & 3.0 & 4.0 & 4.0 & 4.0 & 5.0 & & & \\
\hline & over 20 years & 4.27 & 0.59 & 3.0 & 4.0 & 4.0 & 5.0 & 5.0 & & & \\
\hline \multirow{3}{*}{$\begin{array}{l}\text { Skills in terms } \\
\text { of execution } \\
\text { of diagnosis }\end{array}$} & less than 10 years & 2.48 & 1.18 & 1.0 & 1.0 & 3.0 & 3.0 & 5.0 & \multirow{3}{*}{24.405} & \multirow{3}{*}{2} & \multirow{3}{*}{0.000} \\
\hline & 11-20 years & 3.39 & 0.92 & 1.0 & 3.0 & 3.0 & 4.0 & 5.0 & & & \\
\hline & over 20 years & 3.82 & 0.84 & 2.0 & 3.0 & 4.0 & 4.0 & 5.0 & & & \\
\hline \multirow{3}{*}{$\begin{array}{l}\text { Skills in terms } \\
\text { of therapy }\end{array}$} & less than 10 years & 3.21 & 0.48 & 2.0 & 3.0 & 3.0 & 3.0 & 4.0 & \multirow{3}{*}{43.025} & \multirow{3}{*}{2} & \multirow{3}{*}{0.000} \\
\hline & $11-20$ years & 3.98 & 0.65 & 3.0 & 4.0 & 4.0 & 4.0 & 5.0 & & & \\
\hline & over 20 years & 4.27 & 0.59 & 3.0 & 4.0 & 4.0 & 5.0 & 5.0 & & & \\
\hline
\end{tabular}

$M$ - mean; SD - standard deviation; Min. - minimum value; Max. - maximum value; Q25 - bottom quartile; Me - median; Q75 - top quartile, $X^{2}$ - Kruskal-Wallis test statistic, $p$ - significance.

Statistically significant differences were found between persons with different lengths of work experience concerning knowledge in terms of diagnosis $(p<0.05)$. In case of persons with work experience of up to ten years - for a quarter of teachers analysed in this group the results did not exceed the level of $Q 25=1$, for a half they weren't higher than $M e=2$, and for three quarters of the analysed teachers they weren't higher than $Q 75=3$. In case of persons with work experience between 11 and 20 years, the results were higher and for a quarter of teachers analysed in this group the results did 
not exceed the level of $Q 25=3$, for a half they weren't higher than $M e=3$, and for three quarters of the analysed teachers they weren't higher than $Q 75=4$. Higher results were also recorded for persons with over 20 years of work experience - for a quarter of teachers analysed in this group the results did not exceed the level of $Q 25=3$, for a half they weren't higher than $M e=4$, and for three quarters of the analysed teachers they weren't higher than $Q 75=4$. This means that the longer the work experience of the studied teachers the higher their assessment of their knowledge in terms of diagnosis.

Statistically significant differences were found between persons with different lengths of work experience concerning knowledge in terms of therapy $(p<0.05)$. In case of persons with work experience of up to ten years - for a quarter of teachers analysed in this group the results did not exceed the level of $Q 25=3$, for a half they weren't higher than $M e=3$, and for three quarters of the analysed teachers they weren't higher than $Q 75=3$. In case of persons with work experience between 11 and 20 years, the results were higher and for a quarter of teachers analysed in this group the results did not exceed the level of $Q 25=4$, for a half they weren't higher than $M e=4$, and for three quarters of the analysed teachers they weren't higher than $Q 75=4$. Higher results were also recorded for persons with over 20 years of work experience - for a quarter of teachers analysed in this group the results did not exceed the level of $Q 25=4$, for a half they weren't higher than $M e=4$, and for three quarters of the analysed teachers they weren't higher than $Q 75=5$. This means that the longer the work experience of the studied tachers, the higher their assessment of their knowledge in terms of therapy.

Statistically significant differences were found between persons with different lengths of work experience concerning skills in terms of execution of diagnosis $(p<0.05)$. In case of persons with work experience of up to ten years - for a quarter of teachers analysed in this group the results did not exceed the level of $Q 25=1$, for a half they weren't higher than $M e=3$, and for three quarters of the analysed teachers they weren't higher than $Q 75=3$. In case of persons with work experience between 11 and 20 years, the results were 
higher and for a quarter of teachers analysed in this group the results did not exceed the level of $Q 25=3$, for a half they weren't higher than $M e=3$, and for three quarters of the analysed teachers they weren't higher than $Q 75=4$. Higher results were recorded for persons with over 20 years of work experience - for a quarter of teachers analysed in this group the results did not exceed the level of $Q 25=3$, for a half they weren't higher than $M e=4$, and for three quarters of the analysed teachers they weren't higher than $Q 75=4$. One could make the conclusion that the longer the work experience of the analysed persons, the higher they would assess their skills in terms of diagnosis.

Statistically significant differences were found between persons with different lengths of work experience concerning skills in terms of therapy $(p<0.05)$. In case of persons with work experience of up to ten years - for a quarter of teachers analysed in this group the results did not exceed the level of $Q 25=3$, for a half they weren't higher than $M e=3$, and for three quarters of the analysed teachers they weren't higher than $Q 75=3$. In case of persons with work experience between 11 and 20 years, the results were higher and for a quarter of teachers analysed in this group the results did not exceed the level of $Q 25=4$, for a half they weren't higher than $M e=4$, and for three quarters of the analysed teachers they weren't higher than $Q 75=4$. Higher results were also recorded for persons with over 20 years of work experience - for a quarter of teachers analysed in this group the results did not exceed the level of $Q 25=4$, for a half they weren't higher than $M e=4$, and for three quarters of the analysed teachers they weren't higher than $Q 75=5$. The observation was made that the longer the work experience of the analysed persons, the higher their assessment of their skills in terms of therapy.

\section{Summary and conclusions}

Diagnostic and therapeutic knowledge and skills are competences that a teacher at a special school should have developed to a high level. "Within professionalism, one stresses the significance 
of specific and high competences. This approach also applies to the contemporary teacher - a professional teacher is primarily a competent teacher" 11 .

The presented study concerning the declared sources of teacher knowledge and skills in terms of diagnosis and therapy allowed the formulation of conclusions which, due to the size of the sample, cannot be generalised:

1. The analysed special school teachers declare that their knowledge and skills concerning diagnosis and therapy are primarily competences gained during their professional work (over 85\%), knowledge from own speciality education (over $76 \%$ ) and knowledge gained during private courses (over $50 \%)$.

2. The analysed special school teachers evaluate their knowledge and skills very highly in terms of diagnosis (over 12\%) and therapy (over 19\%), and highly in terms of diagnosis (over $33 \%$ ) and therapy (over 49\%). Knowledge in terms of diagnosis and therapy is assessed by the analysed teachers to be average as well (over 33\%), just like the skills they gained in this area (over $30 \%$ ).

3. The age of the analysed special school teachers is a condition of their self-assessment of their knowledge and skills in terms of diagnosis and therapy. There are statistically significant differences between teachers aged 20-39 years and teachers aged 40 years and over in this regard. Persons aged 40 years and over evaluate their knowledge and skills in terms of diagnosis and therapy higher than younger persons.

4. The work experience of the analysed special school teachers conditions their self-assessment of their skills and capacities in terms od diagnosis and therapy. Statistically significant differences in terms of diagnosis and therapy are found between persons with various work experience.

${ }^{11}$ M. Klimek, Kompetencje op. cit., pp. 167-168. 
Teachers with more work experience assessed their knowledge and skills in terms of diagnosis and therapy higher.

The results of the analysis indicate that teachers of special schools assess their competences in terms of diagnosis and therapy as high. Working with children with special education needs every day, they are specialists in terms of diagnosis and therapy. Their professionalism may shine through in the fact that almost all teachers exhibit additional professional qualifications, including diagnostic and therapeutic ones.

\section{Bibliography}

[1] Borzęcka A., Kompetencje nauczyciela - pedagoga specjalnego w pracy z uczniem ze specjalnymi potrzebami edukacyjnymi, [in:] Nauczyciel-Dziecko. Spotkania w przestrzeni edukacyjnej, ed. A. Borzęcka and A. Twaróg-Kanus, Wydawnictwo LIBRON Filip Lohner, Kraków 2018.

[2] Dykcik W., Wprowadzenie w przedmiot pedagogiki specjalnej jako nauki, [in:] Pedagogika specjalna, ed. W. Dykcik, Wydawnictwo Naukowe UAM, Poznań 2005.

[3] Gajdzica A., Kompetencje nauczyciela we wspótczesnej szkole, [in:] Uczeń niepetnosprawny i jego nauczyciel w przestrzeni szkoty, ed. Z Gajdzica, J. Rottermund, A. Klinik, Oficyna Wydawnicza „Impuls”, Kraków 2008.

[4] M. Klimek, Kompetencje diagnostyczne nauczyciela w kontekście pomocy psychologiczno-pedagogicznej w szkole, Lubelski Rocznik Pedagogiczny, Vol. XXXV, issue 1 - 2016.

[5] Korzon A., Motywy wyboru zawodu pedagoga specjalnego, [in:] Kompetencje pedagoga w kontekście teorii i praktyki edukacji specjalnej, ed. P. Majewicz and A. Mikrut, Oficyna Wydawnicza „Impuls”, Gliwice - Kraków 2008.

[6] T. Pilch, ed., Encyklopedia pedagogiczna XXI wieku, vol. IV, Wydawnictwo „Żak", Warszawa 2004.

[7] Strykowski W., Nauczyciel i jego kompetencje, [in:] Kompetencje nauczyciela szkoty wspótczesnej, ed. by W. Strykowski, J. Strykowska, J. Pielachowski, Wydawnictwo „eMPi2”, Poznań 2007.

[8] Wosik-Kawala D., Zubrzycka-Maciąg T., Kompetencje diagnostyczne i terapeutyczne nauczyciela, Oficyna Wydawnicza „Impuls”, Kraków 2018. 